Article

\title{
Wheat Grinding Process with Low Moisture Content: A New Approach for Wholemeal Flour Production
}

\author{
Waleed H. Hassoon ${ }^{1}$, Dariusz Dziki ${ }^{2, *}$,, Antoni Miś $^{3}$ and Beata Biernacka ${ }^{2}$ \\ 1 Department of Animal Production, Faculty of Agriculture, University of Al-Qasim Green, Babylon 964, Iraq; \\ waleedww27@yahoo.com \\ 2 Department of Thermal Technology and Food Process Engineering, University of Life Sciences in Lublin, \\ 31 Głęboka St., 20-612 Lublin, Poland; beata.biernacka@up.lublin.pl \\ 3 Institute of Agrophysics, Polish Academy of Sciences, Doświadczalna 4, 20-290 Lublin, Poland; \\ a.mis@ipan.lublin.pl \\ * Correspondence: dariusz.dziki@up.lublin.pl; Tel.: +48-81-445-61-25
}

Citation: Hassoon, W.H.; Dziki, D.; Miś, A.; Biernacka, B. Wheat Grinding Process with Low Moisture Content: A New Approach for Wholemeal Flour Production. Processes 2021, 9, 32. https://dx.doi.org/10.3390/ pr9010032

Received: 11 November 2020 Accepted: 23 December 2020 Published: 25 December 2020

Publisher's Note: MDPI stays neutral with regard to jurisdictional claims in published maps and institutional affiliations.

Copyright: () 2020 by the authors. Licensee MDPI, Basel, Switzerland. This article is an open access article distributed under the terms and conditions of the Creative Commons Attribution (CC BY) license (https: / / creativecommons.org/ licenses/by/4.0/).
Abstract: The objective of this study was to determine the grinding characteristics of wheat with a low moisture content. Two kinds of wheat-soft spelt wheat and hard Khorasan wheat-were dried at $45{ }^{\circ} \mathrm{C}$ to reduce the moisture content from $12 \%$ to $5 \%$ (wet basis). Air drying at $45{ }^{\circ} \mathrm{C}$ and storage in a climatic chamber $\left(45^{\circ} \mathrm{C}, 10 \%\right.$ relative humidity) were the methods used for grain dehydration. The grinding process was carried out using a knife mill. After grinding, the particle size distribution, average particle size and grinding energy indices were determined. In addition, the dough mixing properties of wholemeal flour dough were studied using a farinograph. It was observed that decreasing the moisture content in wheat grains from $12 \%$ to $5 \%$ made the grinding process more effective. As a result, the average particle size of the ground material was decreased. This effect was found in both soft and hard wheat. Importantly, lowering the grain moisture led to about a twofold decrease in the required grinding energy. Moreover, the flour obtained from the dried grains showed higher water absorption and higher dough stability during mixing. However, the method of grain dehydration had little or no effect on the results of the grinding process or dough properties.

Keywords: wholemeal flour; particle size; grinding energy; drying; wheat dough

\section{Introduction}

Wheat is one of the most important staple food crops and is used to produce a wide variety of cereal products [1]. The demand for the production of wholemeal flour (WF) has greatly increased during the last decades [2]. WF is rich in nutritive compounds in comparison with refined flour, which mainly contains carbohydrates and protein [3], and is made only with whole grains $(100 \%)$. It also contains minerals, fiber, B vitamins and bioactive compounds having high health-promoting properties [1]. Thus, it helps to reduce the risk of several diseases, such as cardiovascular disorders, type 2 diabetes and some cancers [4], as well as improving intestinal health [5].

Grinding is an important process in WF production and is considered as one of the effective ways to reduce the destructive effects associated with large particles of bran and germ on the end-use products [6,7]. The production process has been well established for refined flour, whereas WF production poses several unique challenges to milling and related industries [3,6]. During the production of WF, mill feeds (bran and germ) are first separated from endosperm using roller mills and then recombined together after the mill feeds. This method of WF production is widely commercialized in the milling industry. However, it is economically unjustified, as the final product often has widely different particle sizes, and all the grain components may not be included in the WF $[3,8]$. 
The process of wheat grinding is influenced by the design of the mill as well as the physical properties of grains, such as hardness $[9,10]$, moisture content [11] and the size of the kernels [12]. During grinding, the endosperm of soft wheat is easily broken up, while that of hard wheat adheres tightly [13]. Thus, less energy is required for grinding soft wheat, and a large number of fine particles are produced [14]. It is extremely important to control the moisture content before the grinding process [15] in order to achieve a higher efficiency of grinding energy [16], adequate particle size of the flour [17] and a high flour yield [18]. Werechowska et al. [16] studied the effect of the grain moisture content (MC) on the wheat milling process. They found that an increase in the MC of wheat from 12 to $18 \%$ decreased the flour yield, increased grinding energy requirements and changed the baking characteristic of the flour. Generally, a higher MC increases the plasticity of the grains and, as a result, the grinding process becomes more difficult and energy-consuming [19]. The milling procedures for refined flour production are wellestablished. During the production of refined flour, some amount of water is usually added into the wheat grains to obtain a bran layer that is resistant to size reduction and to remove it from the endosperm [16]. The optimum MC is usually between $14 \%$ and $17 \%$, and the level of water added to the wheat depends mainly on the grain hardness [18]. However, this kind of wheat tempering is inadequate in the case of wholemeal production. Dry solid grains are brittle and easy to grind, need less energy for size reduction and produce more fine particles of bran [20]. Prabhasankar and Rao [8] studied the wholemeal process of wheat (initial MC of 14\%) using different mills. They found that grinding wheat with such an MC leads to an increase in grain temperature, which has a negative influence on the flour properties [8]. Other authors produced whole wheat flour from grain with MCs of $15 \%$ [21] and $16 \%$ [22]. They found that coarse particles had a negative influence on the gluten network and flour baking quality, whereas research conducted by [23] showed that multistage milling of dried wheat (about $8 \%$ moisture) without tempering allows wholegrain flour with better baking quality than wholegrain flour from tempered wheat (about 16\%) to be obtained. In addition, others studied the wheat wholemeal process (grains of 10-16\% moisture) using an ultracentrifugal mill [24]. According to their study, wheat grain with low MCs (e.g., 10-12\%) produced adequate quality wholemeal flour. However, the mentioned authors [8,21-24] did not study the grinding energy requirements.

The one-stage grinding of wheat grains with low MCs (4-5\% wet basis (w.b.)) has not been examined so far. Grains with low MCs occur in some countries where the summer is very hot and moisture is extremely low in the air. Therefore, this study aimed to assess the grinding process of wheat with low MCs for the production of WF. In particular, the grinding energy indices and physical properties of dough were studied.

\section{Materials and Methods}

\subsection{Material}

Two types of ancient wheat grains were analyzed in the study: Khorasan (Triticum turanicum) and spelt (Triticum spelta, cv. Rokosz). Khorasan wheat is commercially known as $K A M U T^{\circledR}$ Khorasan wheat. Both Khorasan wheat and spelt wheat were purchased in 2019 from a local market in Poland. The chemical compositions of the wheat grains were determined using the methods described by Romankiewicz et al. [25].

\subsection{Characterization of Wheat Grains Using the Single Kernel Characterization System (SKCS)}

A total of 300 individual kernels were tested using the SKCS (model 4100, Perten Instruments AB, Hägersten, Sweden) [26]. The hardness index (HI), weight, MC (w.b.) and kernel thickness of the wheat grains were analyzed using the system. The bulk densities of the grains were also determined [27].

\subsection{Grain Drying}

The grain samples $(1 \mathrm{~kg})$ with an initial MC of about $12 \%$ were dehydrated at $45{ }^{\circ} \mathrm{C}$ using two methods: air drying (ADI) and storage in a climatic chamber. We used the same 
temperature for both methods of drying, because heating the grains to this temperature does not adversely affect the quality of the flour [8]. ADI was performed using a laboratory dryer (SLN 53, POL-EKO-APARATURA, Wodzisław Ślaski, Poland). The relative humidity of the air heated to $45{ }^{\circ} \mathrm{C}$ was $10 \%$ with an air velocity of $0.5 \mathrm{~m} \cdot \mathrm{s}^{-1}$. The process was stopped when the grain weight did not change, which usually required approximately $6 \mathrm{~h}$. Alternatively, the grain samples were stored in a climatic chamber-a controlled incubator (ICH 256, Memmert, Dusseldorf, Germany) at $45^{\circ} \mathrm{C}$ in $10 \%$ air moisture-for 3 weeks. The mass of the grain was controlled every three days, and the storage was stopped when the grain weight did not change. In both cases, the dehydration process was continued until the moisture of the samples decreased up to a level of approximately $5 \%( \pm 0.3 \%)$ w.b. Both before and after drying, the moisture of the grains was assessed by air oven drying (SLN 53, POL-EKO-APARATURA, Poland) at $105^{\circ} \mathrm{C}$ until a constant sample mass was achieved.

\subsection{Grinding Process}

The wheat grains (100 g) were ground using a knife grinder (GRINDOMIX GM-200, Retsch, Haan, Germany; 1000 W, $9000 \mathrm{rpm}$ ). The mill was equipped with a computer system that allowed recording and analyzing of the grinding energy consumption during size reduction. The amount of energy consumed during grinding for 2 min was determined using a digital multimeter (VC 870, VOLTCRAFT ${ }^{\circledR}$, Wollerau, Germany), which was connected to a computer equipped with a special program for recording data (VC870 Interface 4.2.6., VOLTCRAFT ${ }^{\circledR}$, Wollerau, Germany). The grinding energy was estimated as the difference between the total energy $\left(E_{t}\right)$ and the energy lost during idling $\left(E_{i}\right)$. The total energy was determined from the total power consumed during grinding and the grinding time using the following formula [28]:

$$
E_{t}=\int_{0}^{t} P d t(\mathrm{~J})
$$

where $P$ is the power consumed during the grinding process and $t$ is the time of grinding.

The energy lost during idle running $\left(E_{i}\right)$ was calculated as follows:

$$
E_{i}=\int_{0}^{t} P_{j} d t(\mathrm{~J})
$$

where $P_{j}$ is the power consumed during idle running.

After grinding, the samples were screened, and their particle size distributions were analyzed on sieves (AS 200, Retsch, Haan, Germany) having hole sizes of 0.2, 0.3, 0.4, 0.5, $0.6,0.7$ and $0.8 \mathrm{~mm}$. Based on the values, the average particle size $(d)$ was calculated [11]:

$$
d=\frac{\sum_{i=1}^{n} h_{i} P_{i}}{100}(\mathrm{~mm})
$$

The grinding ability index $\left(G_{x i}\right)$ was calculated as the ratio of the surface area $(S)$ of the ground material to the grinding energy $(E)$ [29]:

$$
G_{x i}=\frac{S}{E}\left(\mathrm{~kJ} \cdot \mathrm{m}^{-2}\right)
$$

The surface area of the ground sample was determined using the proposed formula [30]:

$$
S=\frac{6 m}{\rho d} \quad\left(\mathrm{~m}^{2}\right)
$$

where $\rho$ is the density of the wheat (an average density of $1300 \mathrm{~kg} \cdot \mathrm{m}^{-3}$ was assumed) [9]. 
The grinding indices, namely Rittinger $\left(R_{x i}\right)$, Kick $\left(K_{x i}\right)$ and Sokołowski $\left(S_{x i}\right)$, were calculated as follows [31]:

$$
\begin{gathered}
R_{x i}=\frac{E_{r}}{\frac{1}{d}-\frac{1}{D}}\left(\mathrm{~kJ} \cdot \mathrm{kg}^{-1} \cdot \mathrm{mm}\right) \\
K_{x i}=\frac{E_{r}}{\ln D-\operatorname{lnd}}\left(\mathrm{kJ} \cdot \mathrm{kg}^{-1} \cdot \mathrm{mm}^{-1}\right) \\
S_{x i}=\frac{E_{r}}{\frac{1}{\sqrt{d}}-\frac{1}{\sqrt{D}}}\left(\mathrm{~kJ} \cdot \mathrm{kg}^{-1} \cdot \mathrm{mm}^{0.5}\right)
\end{gathered}
$$

where $E_{r}$ is the specific grinding energy and $D$ is the particle size before grinding.

These indices are based on different grinding theories and are used by various authors to describe the grinding process.

\subsection{Physical Properties of the Dough}

The physical properties of the dough were determined during development and mixing using a farinograph (model 810114, Brabender, Duisburg, Germany) equipped with a $50 \mathrm{~g}$ mixer bowl [32]. The parameters measured were the water absorption (WA) of the flour, dough development time (DT), dough stability time (ST), degree of dough softening and farinograph quality number [33].

\subsection{Statistical Analysis}

The grinding process and physical properties of the dough were studied in triplicate. The results were expressed as mean values and standard deviations. In addition, a two-way analysis of variance was performed, and significant differences between the means were determined using Tukey's test $(\alpha=0.05)$. Calculations were done using Statistica 13.0 software (StatSoft, Inc., Tulsa, OK, USA).

\section{Results and Discussion}

\subsection{Moisture Content and Physical Properties of Wheat Grains}

The changes in the physical properties of the studied wheat kernels, determined using the SKCS, are shown in Table 1. The initial MC of the kernels ranged from $11.86 \%$ (Khorasan) to $11.68 \%$ (spelt). The highest hardness was observed for the Khorasan kernels (average $\mathrm{HI}=70.02$ ), whereas significantly lower $\mathrm{HI}$ values were observed for the spelt kernels $(\mathrm{HI}=24.9)$. Based on kernel hardness, Khorasan wheat can be classified as hard wheat and spelt as soft wheat [34]. The mass of the wheat kernels ranged from $40.21 \mathrm{mg}$ (spelt) to $50.87 \mathrm{mg}$ (Khorasan), and their diameters (D) (thickness) varied from 2.16 to $3.12 \mathrm{~mm}$. The studied wheat samples differed significantly in bulk density. The lowest bulk density was found for the spelt grains $\left(745 \mathrm{~kg} \cdot \mathrm{m}^{-3}\right)$ and the highest for the Khorasan grains $\left(793 \mathrm{~kg} \cdot \mathrm{m}^{-3}\right)$. The determined physical properties of the grains indicated the quality and processing characteristics of the wheat $[35,36]$. In particular, the kernel hardness parameter was useful in determining the grinding and baking properties of the wheat $[9,37]$.

Table 1. Initial moisture content and physical properties of the tested wheat.

\begin{tabular}{cccccc}
\hline Type of Wheat & $\begin{array}{c}\text { Moisture Content } \\
(\mathbf{\%} \text { w.b.) }\end{array}$ & $\begin{array}{c}\text { Hardness Index } \\
(-)\end{array}$ & $\begin{array}{c}\text { Diameter } \\
(\mathbf{m m})\end{array}$ & $\begin{array}{c}\text { Mass of Kernel } \\
(\mathbf{m g})\end{array}$ & $\begin{array}{c}\text { Bulk Density } \\
\left(\mathbf{k g ~ m} \mathbf{m}^{-\mathbf{3}}\right)\end{array}$ \\
\hline Khorasan & $11.52 \pm 0.82^{\mathrm{a}, *}$ & $70.0 \pm 13.11^{\mathrm{b}}$ & $3.12 \pm 0.33^{\mathrm{b}}$ & $50.87 \pm 10.12^{\mathrm{b}}$ & $793 \pm 42^{\mathrm{b}}$ \\
Spelt & $11.68 \pm 0.84^{\mathrm{a}}$ & $24.9 \pm 15.63^{\mathrm{a}}$ & $2.16 \pm 0.44^{\mathrm{a}}$ & $40.21 \pm 11.61^{\mathrm{a}}$ & $745 \pm 15^{\mathrm{a}}$ \\
\hline
\end{tabular}

* The values designated with different letters are statistically significantly different $(p<0.05)$. 


\subsection{Grinding Results}

\subsubsection{Particle Size Distribution}

The glanulometric distribution of ground wheat is a very important parameter to determine the end use of flour [3]. Reduction in the MC of wheat caused a decrease in the mass fraction of the coarse particles $(>0.4 \mathrm{~mm})$. In the case of Khorasan wheat, the mass fraction of the coarse particles decreased from $41.9 \%$ to $28.87 \%$ (ADI) and $31.46 \%$ (wheat stored in the climatic chamber (CM)), whereas for spelt this fraction decreased from $30.05 \%$ to $18.25 \%$ (ADI) and $19.2 \%(\mathrm{CM})$. On the other hand, the decrease in grain moisture led to an increase in the mass fraction of particles with a size of $<0.4 \mathrm{~mm}$, from $58.1 \%$ to $71.3 \%$ (ADI) and $68.5 \%$ (CM) and from $70.0 \%$ to $81.8 \%$ (ADI) and $80.8 \%(\mathrm{CM})$ for Khorasan and spelt, respectively (Table 2). The method of grain drying had little influence on the particle size distribution. Furthermore, a higher number of fine particles were produced from soft spelt wheat. This confirms the results reported by other authors for grinding wheat with different hardnesses using a roller mill and a hammer mill $[37,38]$. However, this regularity has been determined for grain with an MC no lower than $10 \%$. We found a similar tendency using a knife mill and for grains with lower moisture contents. MC is a critical parameter, influencing the grinding process of cereal grains. Generally, lowering the MC increases the brittleness of the grains $[16,39]$ and thus makes the grinding process more effective. The tempering of wheat grains by adding water is commonly applied in wheat flour milling to strengthen the bran layer and enhance endosperm fragility $[18,40]$. In the case of WF, the presence of bran particles with a size of $>0.6 \mathrm{~mm}$ reduces the dough mixing properties of flour [41]. Our study showed that decreasing the MC of wheat from $12 \%$ to $5 \%$ reduced this bran fraction by 1.8 to 2.8 times, depending on the method used for drying and the type of wheat.

Table 2. Particle size distribution of ground wheat samples.

\begin{tabular}{ccccccc}
\hline \multirow{2}{*}{ Type of Wheat } & Sample & \multicolumn{5}{c}{ Range of Class (mm) } \\
\cline { 3 - 7 } & & $>\mathbf{0 . 8}$ & $\mathbf{0 . 6 - 0 . 8}$ & $\mathbf{0 . 4 - 0 . 6}$ & $\mathbf{0 . 2 - 0 . 4}$ & $<\mathbf{0 . 2}$ \\
\hline \multirow{3}{*}{ Khorasan } & CW & $2.06 \pm 0.08^{\mathrm{c}, *}$ & $12.44 \pm 0.46^{\mathrm{f}}$ & $27.40 \pm 0.63^{\mathrm{e}}$ & $34.62 \pm 0.57^{\mathrm{a}}$ & $23.48 \pm 0.35^{\mathrm{b}}$ \\
& AD & $0.66 \pm 0.05^{\mathrm{a}}$ & $4.46 \pm 0.05^{\mathrm{e}}$ & $23.75 \pm 0.33^{\mathrm{d}}$ & $44.08 \pm 0.54^{\mathrm{b}}$ & $32.17 \pm 0.60^{\mathrm{c}}$ \\
& CM & $0.85 \pm 0.05^{\mathrm{b}}$ & $7.50 \pm 0.22^{\mathrm{d}}$ & $23.11 \pm 0.40^{\mathrm{c}}$ & $36.94 \pm 0.73^{\mathrm{a}}$ & $31.60 \pm 0.66^{\mathrm{c}}$ \\
\hline \multirow{3}{*}{ Spelt } & CW & $3.35 \pm 0.08^{\mathrm{d}}$ & $7.69 \pm 0.23^{\mathrm{d}}$ & $19.01 \pm 0.31^{\mathrm{b}}$ & $41.68 \pm 0.77^{\mathrm{c}}$ & $28.27 \pm 0.68^{\mathrm{b}}$ \\
& AD & $0.71 \pm 0.06^{\mathrm{a}}$ & $3.70 \pm 0.06^{\mathrm{a}}$ & $13.84 \pm 0.25^{\mathrm{a}}$ & $34.18 \pm 0.84^{\mathrm{a}}$ & $47.57 \pm 1.52^{\mathrm{e}}$ \\
& CM & $1.04 \pm 0.03^{\mathrm{b}}$ & $5.06 \pm 0.18^{\mathrm{c}}$ & $13.10 \pm 0.25^{\mathrm{a}}$ & $43.12 \pm 0.88^{\mathrm{b}}$ & $37.68 \pm 0.73^{\mathrm{d}}$ \\
\hline
\end{tabular}

* The values in columns designated with different letters are statistically significantly different $(p<0.05)$; CW $=$ control wheat before drying, $\mathrm{AD}=$ air-dried wheat and $\mathrm{CM}=$ wheat stored in the climatic chamber

\subsubsection{Average Particle Size and Grinding Energy}

The average particle size $(d)$ and specific grinding energy $\left(E_{r}\right)$ determined for the control and dried wheat samples are presented in Figure 1. The lowest values of these parameters were observed for wheat samples with lower MCs. The values of $d$ for the control ground spelt and Khorasan wheat were 0.33 and $0.37 \mathrm{~mm}$, respectively. Drying resulted in a significant size reduction of the grains and, as a result, $d$ was significantly decreased (on average, to $0.28 \mathrm{~mm}$ for Khorasan wheat and to $0.31 \mathrm{~mm}$ for spelt). The specific grinding energy ranged from 13.2 to $25.3 \mathrm{~kJ} \cdot \mathrm{kg}^{-1}$. The lowest $E_{r}$ value was obtained for spelt grains with low MCs and the highest for Khorasan wheat before drying. Generally, the reduction in the $\mathrm{MC}$ of grains from $12 \%$ to about $5 \%$ decreased the grinding energy requirements, with a range from $27 \%$ (spelt) to $38 \%$ (Khorasan). A similar tendency was also found by other authors when they dried wheat in a microwave oven [42]. When the moisture of the kernels is low, the endosperm and bran can be easily ground, and the specific grinding energy is also lower $[16,43]$ with a reduction in the particle size of the ground material [35]. Our study showed that the method of drying had no significant 
influence on these parameters. This indicates that lowering the moisture of grains via storage at a higher temperature $\left(45^{\circ} \mathrm{C}\right)$ and with low humidity gives similar grinding results to the reduction of grain moisture by faster convective drying. Thus, wheat storage can be carried out in such conditions without grain tempering before WF production. Higher values of $E_{r}$ and $d$ were more often found for the hard Khorasan wheat, compared with the soft spelt. A similar tendency was also reported by other authors [36,44]. Wheat hardness depends mainly on endosperm hardness [45] and is determined by the adherence between starch and protein [46]. A higher adherence resulted in higher energy requirements for size reduction and more coarse particles in the case of the ground Khorasan wheat, compared with the soft spelt grains.
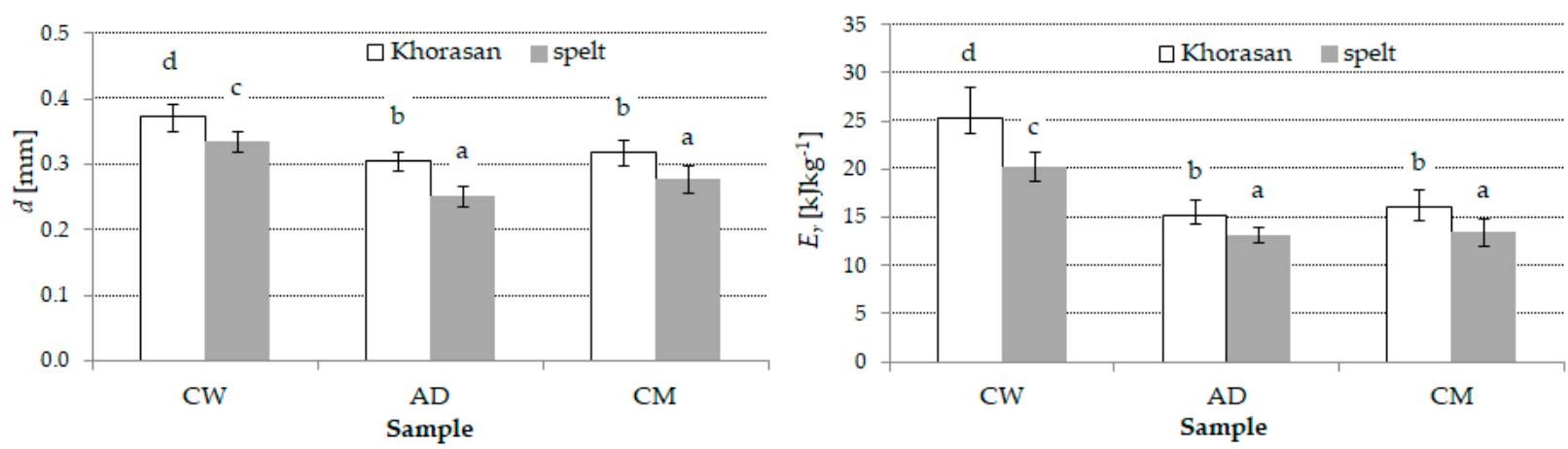

Figure 1. Average particle size $(d)$ and specific grinding energy $\left(E_{r}\right)$ of the control wheat $(\mathrm{CW})$ and the dried wheat $(\mathrm{AD}=$ air-dried wheat, $\mathrm{CM}=$ wheat stored in the climatic chamber). The values in columns designated with different letters are statistically significantly different $(p<0.05)$.

\subsubsection{Grinding Energy Indices}

Figure 2 presents the results of the grinding energy indices. These indices consider both the grinding energy and the particle size of the ground wheat. The highest value of the grinding ability index was often found for the spelt wheat grains. Lowering the MC of the grains caused about a twofold increase in the grinding ability index (on average, from 1.3 to $2.3 \mathrm{~m}^{2} \cdot \mathrm{kJ}^{-1}$ ). This tendency was found for both kinds of wheat and indicated that the grinding process of dry grains ( $5 \%$ moisture) was about two times more effective than the size reduction of wheat grains with an MC of about $12 \%$. Other energy indices also confirmed this effect. The values of Sokołowski's grinding index were 23.6 and $19.4 \mathrm{~kJ} \cdot \mathrm{kg}^{-1} \cdot \mathrm{mm}^{0.5}$ for the control Khorasan and spelt wheat samples, respectively. The decrease in the MC of grains also caused a decrease in the values of this index (on average, to $12.8 \mathrm{~kJ} \cdot \mathrm{kg}^{-1} \cdot \mathrm{mm}^{0.5}$ for the Khorasan wheat and to $10.6 \mathrm{~kJ} \cdot \mathrm{kg}^{-1} \cdot \mathrm{mm}^{0.5}$ for the spelt wheat). In addition, Rittinger's and Kick's grinding indices showed similar changes and about a twofold decrease after reduction in the moisture of the wheat grains. The higher values of these indices were more often found for the hard grains of Khorasan wheat than for spelt wheat. However, the method of moisture reduction had little or no significant influence on these indices. This reveals that storage in hot air with a low relative humidity can be applied to naturally decrease the water content of grains and increase the grinding efficiency of wheat. Other authors also found that the MC and grain hardness of wheat strongly influenced the grinding energy requirements. For instance, Werechowska et al. [16] observed that the specific grinding energy of different common wheat samples increased from 52 to $80 \mathrm{~kJ} \cdot \mathrm{kg}^{-1}$ when the moisture of the grains increased from $12 \%$ to $18 \%$. Letang et al. [47] studied the grinding process of wheat with different hardnesses and found that the values of Sokołowski's grinding index changed from $22 \mathrm{~kJ} \cdot \mathrm{kg}^{-1} \cdot \mathrm{mm}^{0.5}$ for soft wheat to $54 \mathrm{~kJ} \cdot \mathrm{kg}^{-1} \cdot \mathrm{mm}^{0.5}$ for durum wheat. Dziki [11] found about twofold higher values of this index when a hammer mill was used for wheat grinding. 

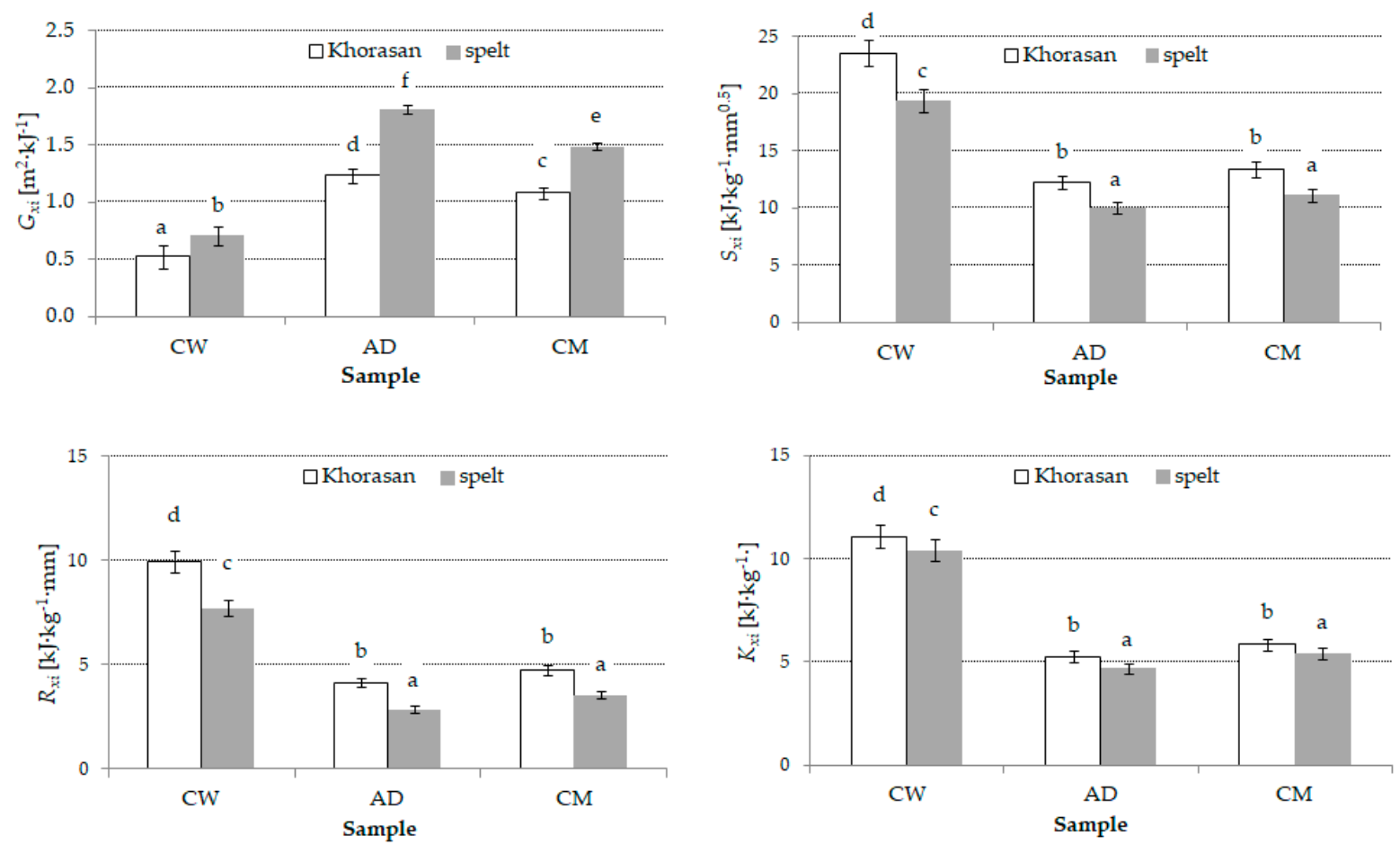

Figure 2. Grinding energy indices of the control wheat $(\mathrm{CW})$ and dried wheat $(\mathrm{AD}=$ air-dried wheat, $\mathrm{CM}=$ wheat stored in the climatic chamber). $G_{x i}=$ grinding ability index, $S_{x i}=$ Sokołowski's grinding index, $R_{x i}=$ Rittinger's grinding index and $K_{x i}=$ Kick's grinding index. The values in columns designated with different letters are statistically significantly different $(p<0.05)$.

\subsection{Farinograph Results}

The farinograph is the leading standard tool for assessing the rheological behavior of wheat dough and the effects of technological and health-promoting additives on the bread dough development and mixing processes [48]. The results of the farinograph measurements obtained in the present study are summarized in Table 3. In the case of spelt wheat flour, WA ranged from $58.2 \%$ to $62.3 \%$, whereas for Khorasan wheat it changed from $57.4 \%$ to $61.6 \%$. Grinding the dried wheat resulted in smaller flour particles and caused a significant increase in WA. This tendency was observed for both kinds of wheat. WA indicates the percentage of water required to yield a dough consistency of $500 \mathrm{BU}$ (Brabender units). Wheat flour is considered to be of good quality when its WA is between $57 \%$ and $62 \%$ [49]. However, the optimum water level differs from flour to flour, depending on the quantity of protein and other dense particles present [50]. WA is directly related to the yield of finished bakery products and is one of the most important parameters in assessing flour strength and in calculating product price because it determines the bread yield as well as quality [51]. The high WA observed for the studied wheat samples could have resulted from the higher bran content of wholemeal wheat. The inclusion of a higher amount of bran in dough formulation resulted in increased WA of the dough due to the higher levels of pentosans and fiber in bran [52]. 
Table 3. Farinograph properties of wheat dough samples.

\begin{tabular}{cccccc}
\hline Type of Wheat & Sample & $\begin{array}{c}\text { Water Absorption } \\
{[\%]^{-}}\end{array}$ & $\begin{array}{c}\text { Development Time } \\
\text { (min) }\end{array}$ & $\begin{array}{c}\text { Stability of Dough } \\
\text { (min) }\end{array}$ & $\begin{array}{c}\text { Degree of Softening } \\
\text { (FU) }\end{array}$ \\
\hline Spelt & CW & $58.2 \pm 0.41^{\mathrm{a}, *}$ & $5.2 \pm 0.24^{\mathrm{a}}$ & $5.8 \pm 0.16^{\mathrm{a}}$ & $62.0^{\mathrm{a}} \pm 2.65^{\mathrm{d}}$ \\
\hline Spelt & $\mathrm{AD}$ & $62.3 \pm 0.82^{\mathrm{c}}$ & $7.3 \pm 0.35^{\mathrm{b}}$ & $10.3 \pm 0.80^{\mathrm{c}}$ & $27.0 \pm 4.53^{\mathrm{b}}$ \\
\hline Spelt & $\mathrm{CM}$ & $61.6 \pm 0.64^{\mathrm{c}}$ & $6.8 \pm 0.41^{\mathrm{b}}$ & $8.7 \pm 0.15^{\mathrm{b}}$ & $38.3 \pm 2.51^{\mathrm{c}}$ \\
\hline Khorasan & $\mathrm{CW}$ & $57.4 \pm 0.46^{\mathrm{a}}$ & $19.5 \pm 0.52^{\mathrm{c}}$ & $15.6 \pm 0.49^{\mathrm{d}}$ & $0.00+0.00^{\mathrm{a}}$ \\
\hline Khorasan & $\mathrm{AD}$ & $61.6 \pm 0.97^{\mathrm{b}, \mathrm{c}}$ & $19.7 \pm 0.46^{\mathrm{c}}$ & $14.8 \pm 0.36^{\mathrm{d}}$ & $0.00+0.00^{\mathrm{a}}$ \\
\hline Khorasan & $\mathrm{CM}$ & $60.9 \pm 0.52^{\mathrm{b}}$ & $20.2 \pm 0.63^{\mathrm{c}}$ & $15.2 \pm 0.52^{\mathrm{d}}$ & $0.00+0.00^{\mathrm{a}}$ \\
\hline
\end{tabular}

${ }^{*}$ The values in columns designated with different letters (a, b, c, d, e and f) are statistically significantly different $(p<0.05)$. CW $=$ control wheat before drying, $\mathrm{AD}=$ air-dried wheat and $\mathrm{CM}=$ wheat stored in the climatic chamber.

The highest DT was often found for Khorasan wheat (average 19.8 min), whereas the lowest values were observed for spelt wheat (average $6.4 \mathrm{~min}$ ) (Table 3). In the case of Khorasan wheat, the decrease in grain moisture before grinding had no significant influence on the DT, whereas a significant increase of this parameter was observed for spelt. DT is an important parameter in determining the mixing behavior of wheat flour. It is defined as the time from the moment water is added to the flour until the dough reaches the maximum consistency [49]. According to Yang et al. [53], the mean DT for white wheat flours usually ranged from 0.9 to $6.7 \mathrm{~min}$, while Kalnina et al. [54] found that the DT was between 2.22 and $6.8 \mathrm{~min}$. The results obtained for dough DT in the present study demonstrated that wholegrain flour obtained from Khorasan wheat required a greater mixing time to achieve the maximum consistency than the spelt wheat flour. This was probably caused by the higher protein content in Khorasan wheat in comparison with spelt wheat. The dough DT depends on protein quality and quantity, starch granule size and the degree of starch damage [55]. Furthermore, dough DT increases with the increase in protein degradation (proteolysis). It also increases with a decrease in the size of the starch granules and an increase in the content of damaged starch, due to the increase in the specific surface area absorbing water [51].

The most important farinograph parameter is ST. ST is defined as the difference between the arrival time and departure time and is generally considered a good indicator of dough strength. In the present study, the stability time of the tested wheat flour samples ranged from 5.8 to $15.6 \mathrm{~min}$. The highest dough ST was found for the flour obtained from Khorasan wheat, whereas the lowest values were found for spelt wheat (Table 3). These differences can be explained by the lower protein content in spelt wheat than Khorasan wheat and a weaker gluten network. Similar effects were observed by Bae et al. [56] in different samples of wheat flour. Interestingly, in the case of spelt and Khorasan wheat dough obtained from the flour with more fine particles (dried grains), a significant increase in ST was observed. Boita et al. [57] found that the stability time of dough was $13.8 \mathrm{~min}$ for refined wheat flour, whereas it averaged $8.9 \mathrm{~min}$ for whole wheat flour. This effect can be attributed to the interaction between fiber and gluten, which prevents protein hydration. The bran particles can react directly with the structural elements of the gluten network and, as a result, the dough extensibility, stability and damaging gas retention decrease [58].

The data shown in Table 3 revealed that dough softening was observed only in the case of spelt flour. The dough obtained from Khorasan wheat was characterized by such a strong structure that the degree of softening after $12 \mathrm{~min}$ of mixing was equal to zero. Interestingly, the flour obtained from dried spelt showed a lower degree of dough softening than the control flour. An increased degree of softening is a particularly important indicator of proteolytic degradation of gluten [51]. A high WA of the flour and a low degree of softening indicate that the flour is of good quality, whereas a low WA and a high degree of softening indicate poor quality [57]. The results showed that, in the case of spelt wheat, the drying process allowed for obtaining more fine bran particles, which has a positive 
effect on the dough properties. On the other hand, the method of grain dehydration had no significant influence on the physical properties of wheat dough.

\section{Conclusions}

Decreasing the content of moisture in wheat grains from $12 \%$ to $5 \%$ had a significant influence on the grinding process of wheat. The mass fraction of coarse particles significantly decreased, whereas that of fine particles increased. This tendency was found for both the soft and hard wheat samples studied. Lowering the grain moisture also caused a significant decrease in grinding energy requirements. The values of the Rittinger, Kick and Sokołowski indices were found to be decreased about twofold when grains with a low moisture content $(5 \%)$ were ground in comparison with the values obtained for the control wheat (12\% moisture). Importantly, the flour obtained from dried grains was characterized by a higher WA and higher dough stability during mixing. According to the results, the method of grain dehydration (ADI and storage of grains for 3 weeks in the climatic chamber) had little or no effect on the results of grinding or the dough properties. Therefore, natural drying is recommended for wheat grains. Natural drying is possible in some countries during the summer, when the moisture of air ranges between $5 \%$ and $15 \%$ and the temperature exceeds $40^{\circ} \mathrm{C}$. Such conditions allow for obtaining wheat grains with a low $\mathrm{MC}$, and the grains can be used without tempering for WF production.

Author Contributions: Conceptualization, D.D. and W.H.H.; methodology, D.D.; formal analysis, D.D. and B.B.; investigation, W.H.H., D.D. and A.M.; writing — original draft preparation, W.H.H. and D.D.; writing-review and editing, D.D. and B.B.; supervision, D.D. All authors have read and agreed to the published version of the manuscript.

Funding: This research received no external funding.

Institutional Review Board Statement: Not applicable.

Informed Consent Statement: Not applicable.

Data Availability Statement: The data presented in this study are available on request from the corresponding author.

Conflicts of Interest: The authors declare no conflict of interest

$\begin{array}{ll}\text { Abbreviations } \\ \text { ADI } & \text { air drying } \\ \text { CM } & \text { wheat stored in climatic chamber } \\ \text { DT } & \text { development time } \\ \text { d } & \text { average particle size } \\ \mathrm{E}_{\mathrm{r}} & \text { specific grinding energy } \\ \text { MC } & \text { moisture content } \\ \text { ST } & \text { dough stability time } \\ \text { WA } & \text { water absorption of flour }\end{array}$

\section{References}

1. Giraldo, P.; Benavente, E.; Manzano-Agugliaro, F; Gimenez, E. Worldwide research trends on wheat and barley: A bibliometric comparative analysis. Agronomy 2019, 9, 352. [CrossRef]

2. Seal, C.J.; Nugent, A.P.; Tee, E.S.; Thielecke, F. Whole-grain dietary recommendations: The need for a unified global approach. $B r$. J. Nutr. 2016, 115, 2031-2038. [CrossRef] [PubMed]

3. Doblado-Maldonado, A.F.; Pike, O.A.; Sweley, J.C.; Rose, D.J. Key issues and challenges in whole wheat flour milling and storage. J. Cereal Sci. 2012, 56, 119-126. [CrossRef]

4. Adom, K.K.; Sorrells, M.E.; Rui, H.L. Phytochemicals and antioxidant activity of milled fractions of different wheat varieties. J. Agric. Food Chem. 2005, 53, 2297-2306. [CrossRef]

5. Călinoiu, L.F.; Vodnar, D.C. Whole grains and phenolic acids: A review on bioactivity, functionality, health benefits and bioavailability. Nutrients 2018, 10, 1615. [CrossRef]

6. Niu, M.; Hou, G.G.; Wang, L.; Chen, Z. Effects of superfine grinding on the quality characteristics of whole-wheat flour and its raw noodle product. J. Cereal Sci. 2014, 60, 382-388. [CrossRef] 
7. Talbert, L.E.; Hofer, P.; Nash, D.; Martin, J.M.; Lanning, S.P.; Sherman, J.D.; Giroux, M.J. Hard white versus hard red wheats: Taste tests and milling and baking properties. Cereal Chem. 2013, 90, 249-255. [CrossRef]

8. Prabhasankar, P.; Haridas Rao, P. Effect of different milling methods on chemical composition of whole wheat flour. Eur. Food Res. Technol. 2001, 213, 465-469. [CrossRef]

9. Dziki, D.; Cacak-Pietrzak, G.; Miś, A.; Jończyk, K.; Gawlik-Dziki, U. Influence of wheat kernel physical properties on the pulverizing process. J. Food Sci. Technol. 2012, 51, 2648-2655. [CrossRef]

10. Choy, A.L.; Walker, C.K.; Panozzo, J.F. Investigation of wheat milling yield based on grain hardness parameters. Cereal Chem. 2015, 92, 544-550. [CrossRef]

11. Dziki, D. Effect of preliminary grinding of the wheat grain on the pulverizing process. J. Food Eng. 2011, 104, 585-591. [CrossRef]

12. Baasandorj, T.; Ohm, J.B.; Manthey, F.; Simsek, S. Effect of kernel size and mill type on protein, milling yield, and baking quality of hard red spring wheat. Cereal Chem. 2015, 92, 81-87. [CrossRef]

13. Haddad, Y.; Mabille, F.; Mermet, A.; Abecassis, J.; Benet, J.C. Rheological properties of wheat endosperm with a view on grinding behaviour. Powder Technol. 1999, 105, 89-94. [CrossRef]

14. Dziki, D.; Cacak-Pietrzak, G.; Gawlik-Dziki, U.; Świeca, M.; Miś, A.; Rózyło, R.; Jończyk, K. Physicochemical properties and milling characteristics of spring wheat from different farming systems. J. Agric. Sci. Technol. 2017, 19, $1253-1266$.

15. Jung, H.; Lee, Y.J.; Yoon, W.B. Effect of moisture content on the grinding process and powder properties in food: A review. Processes 2018, 6, 69. [CrossRef]

16. Warechowska, M.; Markowska, A.; Warechowski, J.; Miś, A.; Nawrocka, A. Effect of tempering moisture of wheat on grinding energy, middlings and flour size distribution, and gluten and dough mixing properties. J. Cereal Sci. 2016, 69, 306-312. [CrossRef]

17. Cappelli, A.; Guerrini, L.; Parenti, A.; Palladino, G.; Cini, E. Effects of wheat tempering and stone rotational speed on particle size, dough rheology and bread characteristics for a stone-milled weak flour. J. Cereal Sci. 2020, 91, 102879. [CrossRef]

18. Kweon, M.; Martin, R.; Souza, E. Effect of tempering conditions on milling performance and flour functionality. Cereal Chem. 2009, 86, 12-17. [CrossRef]

19. Dziki, D. The crushing of wheat kernels and its consequence on the grinding process. Powder Technol. 2008, 185, 181-186. [CrossRef]

20. Acquisgrana, M.D.R.; Gomez Pamies, L.C.; Martinez Amezaga, N.M.J.; Quiroga, F.M.; Ribotta, P.D.; Benítez, E.I. Impact of moisture and grinding on yield, physical, chemical and thermal properties of wholegrain flour obtained from hydrothermally treated sorghum grains. Int. J. Food Sci. Technol. 2020, 55, 2901-2909. [CrossRef]

21. Bressiani, J.; Oro, T.; Da Silva, P.M.L.; Montenegro, F.M.; Bertolin, T.E.; Gutkoski, L.C.; Gularte, M.A. Influence of milling whole wheat grains and particle size on thermo-mechanical properties of flour using Mixolab. Czech J. Food Sci. 2019, 37, $276-284$. [CrossRef]

22. Kihlberg, I.; Johansson, L.; Kohler, A.; Risvik, E. Sensory qualities of whole wheat pan bread-Influence of farming system, milling and baking technique. J. Cereal Sci. 2004, 39, 67-84. [CrossRef]

23. Doblado-Maldonado, A.F.; Flores, R.A.; Rose, D.J. Low moisture milling of wheat for quality testing of wholegrain flour. J. Cereal Sci. 2013, 58, 420-423. [CrossRef]

24. Khalid, K.H.; Manthey, F.; Simsek, S. Whole grain wheat flour production using an ultracentrifugal mill. Cereal Chem. 2017, 94, 1001-1007. [CrossRef]

25. Romankiewicz, D.; Hassoon, W.H.; Cacak-Pietrzak, G.; Sobczyk, M.B.; Wirkowska-WojdyBa, M.; CegliNska, A.; Dziki, D. The effect of chia seeds (Salvia hispanica L.) addition on quality and nutritional value of wheat bread. J. Food Qual. 2017, $2017,1-7$. [CrossRef]

26. Sissons, M.J.; Osborne, B.G.; Hare, R.A.; Sissons, S.A.; Jackson, R. Application of the single-kernel characterization system to durum wheat testing and quality prediction. Cereal Chem. 2000, 77, 4-10. [CrossRef]

27. Kraszewski, A.W.; Nelson, S.O. Determination of Moisture Content and Bulk Density of Shelled Corn by Measurement of Microwave Parameters. J. Agric. Eng. Res. 1994, 58, 37-46. [CrossRef]

28. Ziemichód, A.; Wójcik, M.; Różyło, R. Seeds of Plantago psyllium and Plantago ovata: Mineral composition, grinding, and use for gluten-free bread as substitutes for hydrocolloids. J. Food Process Eng. 2019, 42, e12931. [CrossRef]

29. Dziki, D.; Laskowski, J. Study to analyze the influence of sprouting of the wheat grain on the grinding process. J. Food Eng. 2010, 96, 562-567. [CrossRef]

30. Velu, V.; Nagender, A.; Prabhakara Rao, P.G.; Rao, D.G. Dry milling characteristics of microwave dried maize grains (Zea mays L.). J. Food Eng. 2006, 74, 30-36. [CrossRef]

31. Dziki, D.; Gładyszewska, B.; Różyło, R.; Polak, R.; Rudy, S.; Krzykowski, A. The size reduction theories of solid foods. Teka Comm. Mot. Power Ind. Agric. 2012, 12, 41-45.

32. Miś, A.; Nawrocka, A.; Dziki, D. Behaviour of Dietary Fibre Supplements During Bread Dough Development Evaluated Using Novel Farinograph Curve Analysis. Food Bioprocess Technol. 2017, 10, 1031-1041. [CrossRef]

33. Miś, A. Interpretation of mechanical spectra of carob fibre and oat wholemeal-enriched wheat dough using non-linear regression models. J. Food Eng. 2011, 102, 369-379. [CrossRef]

34. Pearson, T.; Wilson, J.; Gwirtz, J.; Maghirang, E.; Dowell, F.; McCluskey, P.; Bean, S. Relationship between single wheat kernel particle-size distribution and Perten SKCS 4100 hardness index. Cereal Chem. 2007, 84, 567-575. [CrossRef] 
35. Muhamad, I.I.; Campbell, G.M. Effects of kernel hardness and moisture content on wheat breakage in the single kernel characterisation system. Innov. Food Sci. Emerg. Technol. 2004, 5, 119-125. [CrossRef]

36. Dziki, D.; Laskowski, J. Wheat kernel physical properties and milling process. Acta Agrophys. 2005, 6, 59-71.

37. Pasha, I.; Anjum, F.M.; Morris, C.F. Grain hardness: A major determinant of wheat quality. Food Sci. Technol. Int. 2010, 16, 511-522. [CrossRef]

38. Świeca, M.; Dziki, D.; Gawlik-Dziki, U.; Rózyło, R.; Andruszczak, S.; Kraska, P.; Kowalczyk, D.; Pałys, E.; Baraniak, B. Grinding and nutritional properties of six spelt (Triticum aestivum ssp. Spelta L.) cultivars. Cereal Chem. 2014, 91, 247-254. [CrossRef]

39. Wang, N.; Hou, G.G.; Dubat, A. Effects of flour particle size on the quality attributes of reconstituted whole-wheat flour and Chinese southern-type steamed bread. LWT Food Sci. Technol. 2017, 82, 147-153. [CrossRef]

40. Fang, C.; Campbell, G.M. On predicting roller milling performance V: Effect of moisture content on the particle size distribution from first break milling of wheat. J. Cereal Sci. 2003, 37, 31-41. [CrossRef]

41. Zhang, D.; Moore, W. Wheat bran particle size effects on bread baking performance and quality. J. Sci. Food Agric. 1999, 79, 805-809. [CrossRef]

42. Walde, S.G.; Balaswamy, K.; Velu, V.; Rao, D.G. Microwave drying and grinding characteristics of wheat (Triticum aestivum). J. Food Eng. 2002, 55, 271-276. [CrossRef]

43. Ahmed, Z.A.; Nadulski, R.; Kobus, Z.; Zawiślak, K. The Influence of Grain Moisture Content on Specific Energy During Spring Wheat Grinding. Agric. Agric. Sci. Procedia 2015, 7, 309-312. [CrossRef]

44. Turnbull, K.M.; Rahman, S. Endosperm texture in wheat. J. Cereal Sci. 2002, 36, 327-337. [CrossRef]

45. Topin, V.; Radjaï, F.; Delenne, J.Y.; Mabille, F. Mechanical modeling of wheat hardness and fragmentation. Powder Technol. 2009, 190, 215-220. [CrossRef]

46. Topin, V.; Radjaï, F.; Delenne, J.Y.; Sadoudi, A.; Mabille, F. Wheat endosperm as a cohesive granular material. J. Cereal Sci. 2008, 47, 347-356. [CrossRef]

47. Pujol, R.; Létang, C.; Lempereur, I.; Chaurand, M.; Mabille, F.; Abecassis, J. Description of a micromill with instrumentation for measuring grinding characteristics of wheat grain. Cereal Chem. 2000, 77, 421-427. [CrossRef]

48. Miś, A.; Grundas, S.; Dziki, D.; Laskowski, J. Use of farinograph measurements for predicting extensograph traits of bread dough enriched with carob fibre and oat wholemeal. J. Food Eng. 2012, 108, 1-12. [CrossRef]

49. Temea, A.M.; Pircu, N.; Simion, A.I.; Grigoraş, C.G.; Ungureanu, R.E.; Alexe, P. Improvement of flour and dough rheological properties by maturation process. Rom. Biotechnol. Lett. 2016, 21, 11381-11392.

50. Bakare, A.H.; Osundahunsi, O.F.; Olusanya, J.O. Rheological, baking, and sensory properties of composite bread dough with breadfruit (Artocarpus communis Forst) and wheat flours. Food Sci. Nutr. 2016, 4, 573-587. [CrossRef]

51. Dapcevic, T.; Pojic, M.; Hadnaev, M.; Torbic, A. The Role of Empirical Rheology in Flour Quality Control. In Wide Spectra of Quality Control; IntechOpen: London, UK, 2011.

52. Sanz Penella, J.M.; Collar, C.; Haros, M. Effect of wheat bran and enzyme addition on dough functional performance and phytic acid levels in bread. J. Cereal Sci. 2008, 48, 715-721. [CrossRef]

53. Yang, X.; Wu, L.; Zhu, Z.; Ren, G.; Liu, S. Variation and trends in dough rheological properties and flour quality in $330 \mathrm{Chinese}$ wheat varieties. Crop J. 2014, 2, 195-200. [CrossRef]

54. Kalnina, S.; Rakcejeva, T.; Kunkulberga, D. Rheological properties of whole grain wheat, rye and hull-less barley flour blends for pasta production. Res. Rural Dev. 2015, 1, 150-156.

55. Rosell, C.M.; Santos, E.; Collar, C. Mixing properties of fibre-enriched wheat bread doughs: A response surface methodology study. Eur. Food Res. Technol. 2006, 223, 333-340. [CrossRef]

56. Bae, W.; Lee, B.; Hou, G.G.; Lee, S. Physicochemical characterization of whole-grain wheat flour in a frozen dough system for bake off technology. J. Cereal Sci. 2014, 60, 520-525. [CrossRef]

57. Boita, E.R.F.; Oro, T.; Bressiani, J.; Santetti, G.S.; Bertolin, T.E.; Gutkoski, L.C. Rheological properties of wheat flour dough and pan bread with wheat bran. J. Cereal Sci. 2016, 71, 177-182. [CrossRef]

58. Noort, M.W.J.; van Haaster, D.; Hemery, Y.; Schols, H.A.; Hamer, R.J. The effect of particle size of wheat bran fractions on bread quality-Evidence for fibre-protein interactions. J. Cereal Sci. 2010, 52, 59-64. [CrossRef] 